In cooperation with the City of Hamilton and the Hamilton to New Baltimore Ground Water Consortium

\title{
Ground-Water Flow Directions and Estimation of Aquifer Hydraulic Properties in the Lower Great Miami River Buried Valley Aquifer System, Hamilton Area, Ohio
}
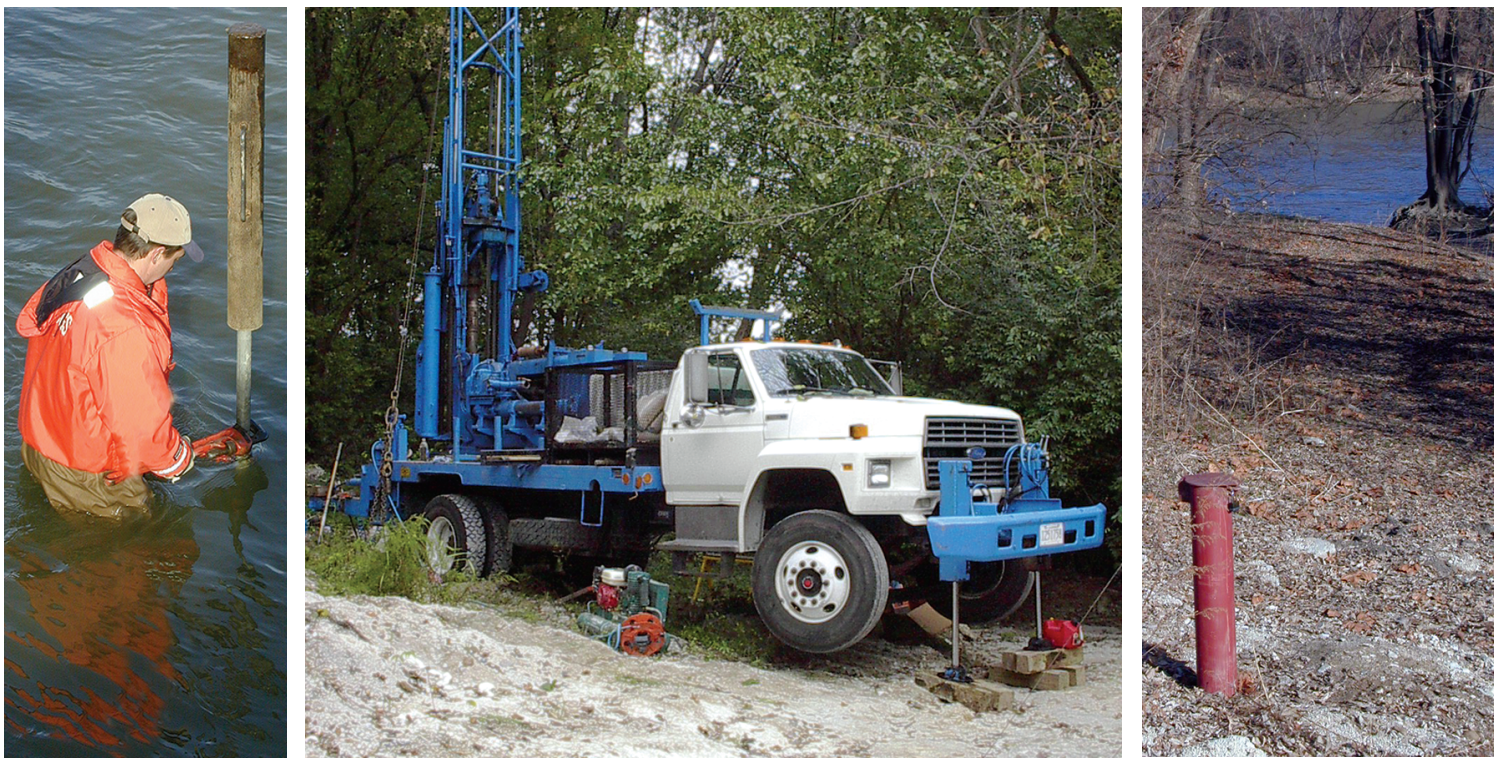

Scientific Investigations Report 2005-5013

U.S. Department of the Interior US. Geological Sunvey 
Cover photos by Rob Darner (left) and Jim Rauman (middle and right), U.S. Geological Survey. 


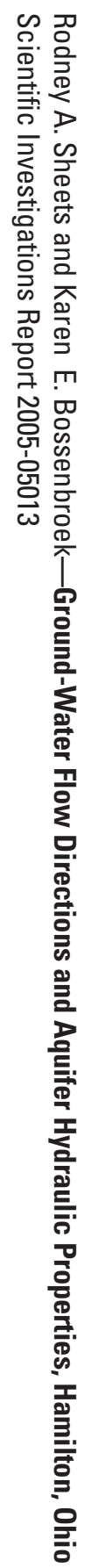

9 Printed on recycled paper 